\title{
Land Use and Land Cover Change in Khorezm, Uzbekistan
}

\author{
Sherzod Rakhmonov ${ }^{1, *}$, Uktam Umurzakov ${ }^{1}$, Kosimdjon Rakhmonov ${ }^{1}$, Iqbol Bozarov ${ }^{1}$ and \\ Ozodbek Karamatov ${ }^{2}$ \\ ${ }^{1}$ Tashkent Institute of Irrigation and Agricultural Mechanization Engineers (TIIAME), Department of \\ Geodesy and Geoinformatics, 100000 Tashkent, Uzbekistan \\ ${ }^{2}$ Kastamonu University, Department of Economics, 37150 Kastamonu, Turkey
}

\begin{abstract}
This article depicts on discussions about land use and land cover change distribution in Khorezm province, Uzbekistan between 1987 and 2019. For the study Landsat 5 TM and Landsat 8 OLI respectively used to detect land use changes in the study area. Khorezm region affected by Aral Sea shrinkage having received salt wind from northeast of the region. Moreover, population increased within study period, making population density intense. Research is carried out to detect reflection of ecology and density in land use. RS techniques - maximum likelihood employed to classify land use to generate land cover distribution map. In total seven class selected such as agricultural land, built up, bare land, lowland, saline land, sand and waterbody. The research of Khorezm region for 32 years has been thoroughly studied and found out that agricultural land, built up and saline land increased tremendously while lowland and bare soil are decreased accordingly. The result map can be used for decision makers and government bodies for future long term urban and regional planning.
\end{abstract}

\section{Introduction}

Land Use and Land Cover (LULC) terms are two separate terms which corresponds to physical properties of land surface electromagnetic elements and human eye perception of land cover $[1,2]$. Therefore, it is not separated in use and the term broadly used among remote sensing scientists. LULC changes represents result of human activity influence on surrounding area [3-7]. Multi-spectral data is widely used among RS researchers to detect and learn timely temporal changes of human-environment interaction as well as natural disaster on land use [8-12].

US Geological Survey has launched satellites with remote sensors to orbit. Geological Survey provides remotely sensed data publicly available to anyone via earthexplorer.usgs.gov. RS researchers use freely available geodata with good resolution and timely updates. Researcher all over the world use the geoportal to carry out research to detect land cover changes on a timely base $[13,14]$. RS offers different approaches and

* Corresponding author: sherzod.rakhmonov@tiiame.uz 
methodologies such as maximum likelyhood, principal component analysis and interactive supervised classification to work on geodata.

Various articles related to remote sensing research results on Central Asian countries are studied in this research. Yin et al [14] delivered results of a forest cover map for Central Asian countries. Interactive supervised classification applied to MODIS and Landsat geodata to generate a forest map. Kraemer et al. [15] analyzed Kostanay region in Kazakhstan to detect LULC changes. Multi-spatio-temporal Landsat geodata is analyzed using Support Vector Machine method to develop agricultural land using geoinformation between 1953-2010. Edlinger et al. [16] applied RS technique with Landsat MSS and TM geodata for 1972-2000. Research result compared with local geodata delivered quite good result which detected irrigated land in Kashkadarya region, Uzbekistan.

Aral Sea has been decreased starting from 1970s. Almost vanished Aral Sea resulted in water scarcity and strong northeast wind delivering salt and dust to surrounding area, including Khorezm province. Khorezm province is located $400 \mathrm{~km}$ away from Aral Sea and hence chosen for study for this research to detect how ecology resulted to the site.

Khorezm is located in the northwestern part of Uzbekistan and bordered with Turkmenistan on southwest. It was established on January 15, 1938 with 6,0 thousand $\mathrm{km}^{2}$ area. The population is about $1.8 \mathrm{mln}$. people, consisting of mostly Uzbeks, as well as Turkmen, Russian, Kazakh, Tatar, Korean, Karakalpak and other nationalities. The average population density is 300 people per $1 \mathrm{~km}^{2}$ (2017). Khorezm has 10 districts, 3 cities, 7 towns, 100 village - communities. Its capital is Urgench city.

\section{Materials and methods}

\subsection{Study Area}

Khorezm is located between $41^{\circ} 01^{\prime}$ and $42^{\circ} 05^{\prime}$ north and $60^{\circ} 11^{\prime}$ and $62^{\circ} 15^{\prime}$ east. The territory of the region is placed on the left bank of the Amudarya downstream, on the northern part of the Khorezm has lowland oasis at an average height of $100 \mathrm{~m}$. Khorezm's west and southwest sides borders with the sandy Karakum Desert. The fossil minerals include limestone, sand, clay and others. The climate is sharp continental. The winter is moderately cold and light snow. The average temperature in January is $-5^{\circ} \mathrm{C}$, the lowest temperature is $-32^{\circ} \mathrm{C}$. The summer is hot and dry, the average temperature July is $30^{\circ} \mathrm{C}$ and the highest temperature is $45^{\circ} \mathrm{C}$. Vegetation period is $200-210$ days a year. The rainfall is 78-79 mm per year, it mostly rains in March-April. North and northeast winds blow in the area. The Amudarya River is the only river that runs through the valley. Water is used to irrigate crops through large canals. In the south of the region there are small salt lakes, marshes and salts. Meadow soils is spread over river valleys and sands to the west. The irrigated land is mainly high salinized. Poplar, willow, oleander, owl, sandy saxaul and other species grow on the shores of the Amu Darya river.

Regions main agriculture consists of cotton and grain. Horticulture, vegetable growing, gardening, cattle breeding and silkworm breeding also developed. Cotton, grain, potatoes, vegetables are planted on the fields. Khorezm region ranks number one in the country for rice cultivation. Cattle, sheep and goats, poultry are raised in commune and private farms. There are plants and factories in Urgench and Khiva cities.

The Tashkent-Moscow, Dushanbe-Moscow-Tashkent railway runs through the region and as well as Urgench-Tashkent. The length of the railway is $128 \mathrm{~km}$ long. The Khazarasp railway bridge over the Amudarya River was put into operation recently. The length of roads in the region is $2750 \mathrm{~km}$. The trolleybus route from Khiva to Urgench was launched in 1997. Buses run from Urgench, Khiva to Tashkent, Samarkand, Navoi, Bukhara, Nukus 
and other cities. Urgench international and domestic airports have regular air communication with foreign countries. Central Asia - Center, Bukhara - Uralsk, Turkmenistan - Russia international gas main pipelines run through the region.

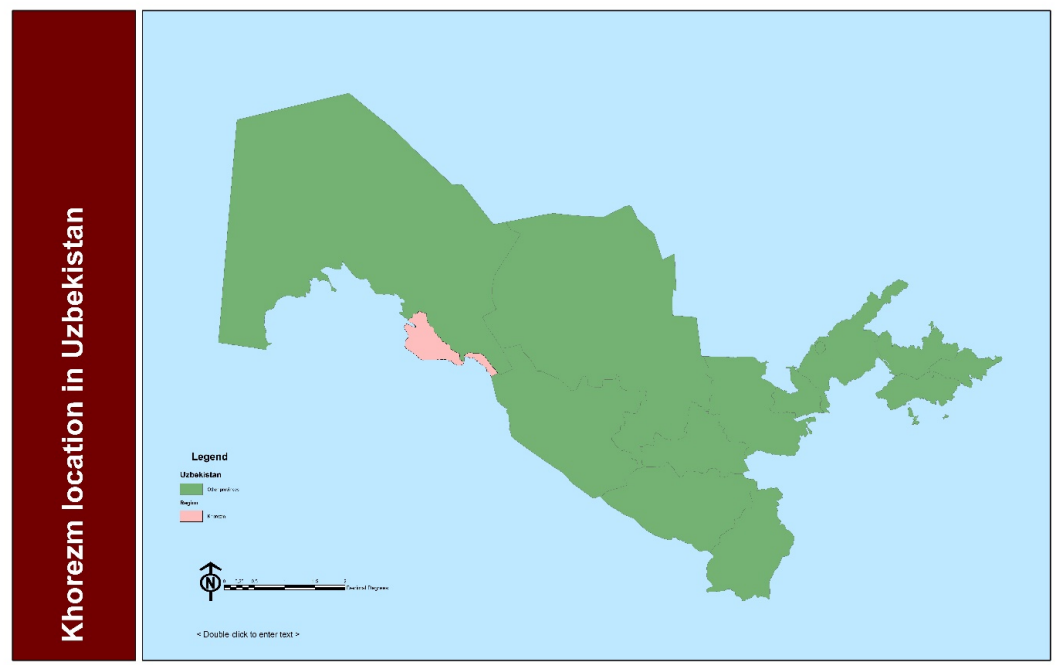

Fig. 1. Location of the study area.

There are 538 secondary schools in the region (including 28 lyceums and gymnasiums), 57 professional colleges and secondary specialized educational institutions, Urgench University, Urgench branch of Tashkent Medical Academy. 36 hospitals and 211 medical institutions, clinics, outpatient clinics, rural hospitals. Urgench branch of the State Scientific Center for Emergency Medical Care and its subdivisions are established at all district central hospitals.

\subsection{Data Preparation and Processing}

Landsat 5 TM data of 20 July 1987 and Landsat 8 data of 12 July 2019 derived from Geological website (earthexplorer.usgs.gov). The spatial resolution of Landsat $5 \mathrm{TM}$ and 8 OLI is 30 meter. The study area is mostly plane and lowland oasis. Ground reference interpretation was done via visual gaining information from Google maps, Google Earth and as well as from local cadastral data. ArcGIS 10.3 software was used to process the Landsat geodata. The preprocessing included assigning coordinate system to data, radiometric correction, layer stacking of separate bands of datasets, mosaic the stack of bands and generating polygons after process.

Radiometric correction is a technique to correct or reduce errors in digital numbers of remote sensed data. This technique is, due to inconsistencies during different times of the geodata collection, important when comparing two datasets of different time of period. Radiometric errors must be corrected to obtain a true ground radiance and reflectance values. Radiometric correction is applied using values taking into account effects of satellite sensors, angle of sun, topography and atmosphere [19].

Maximum likelihood algorithm is popular and was used effectively in assessing satellite imageries [17]. At the end, seven types of LULC classes were derived from study area: agricultural land, bare soil, waterbodies, built-up areas, lowland, sandy area, saline land. In order to get accurate results, 18 training samples for each land use were collected and generated sample signature. Finally, to find out change detection results a post- 
classification method was applied, and the LULC change direction and change detection matrix between initial and final states was evaluated.

\section{Results and Discussions}

All classes were named generally and they may further be divided into subclasses, such as Agricultural Land, which also included crop fields and fallow fields (cotton field, grain, garden and rice field); Bare Soil, which included rock, stony and unused land plots; Waterbodies, which included both rivers, lakes and reservoir; Built-Up areas, which included residential, commercial and industrial subclasses; Saline Land which includes salinized land, land where water left saline land behind; Lowland which includes hilly areas that does not have vegetation and finally the Sand that are covered with sand. Selected signature fits nomenclature system adopted in Uzbekistan.

In Fig. 2 and 3 the spatial distribution of LULC for 1987 and 2019 years is provided. The classified image for 1987 is divided into seven classes, with $51.5 \%\left(3098,54 \mathrm{~km}^{2}\right)$ of the area covered with agricultural land, $2.1 \%\left(123,86 \mathrm{~km}^{2}\right)$ with built up, $12.4 \%(746,17$ $\left.\mathrm{km}^{2}\right)$ with bare land, $7.5 \%\left(453,79 \mathrm{~km}^{2}\right)$ with lowland areas, $20.2 \%\left(1216,21 \mathrm{~km}^{2}\right)$ with sandy land, 5.5\% $\left(332,47 \mathrm{~km}^{2}\right)$ with water and $0.8 \%\left(50,78 \mathrm{~km}^{2}\right)$ with Saline Land. About $60.8 \%\left(3661,08 \mathrm{~km}^{2}\right)$ of the area of the 2017 image is classified as agricultural land, $10.1 \%$ $\left(610.8 \mathrm{~km}^{2}\right)$ as built-up areas, $1.8 \%\left(109,23 \mathrm{~km}^{2}\right)$ as bare land, $0.4 \%\left(23,47 \mathrm{~km}^{2}\right)$ as lowland areas, $0.4 \%\left(730,06 \mathrm{~km}^{2}\right)$ as sand, $4.8 \%\left(288.01 \mathrm{~km}^{2}\right)$ as water and $9.9 \%(6021,82$ $\left.\mathrm{km}^{2}\right)$ as built-up areas. We can see that agricultural land gained $562.54 \mathrm{~km}^{2}(+18.2 \%)$, built up area increased by $486.94 \mathrm{~km}^{2}(+393.1 \%)$, and salinized land by $548.39 \mathrm{~km}^{2}(+1079.9 \%)$. Bare land decreased by $636.9 \mathrm{~km}^{2}(-85.4 \%)$, lowland areas by $430.32 \mathrm{~km}^{2}(-94.8 \%)$, sandy land by $486.15 \mathrm{~km}^{2}(-40 \%)$, and finally waterbody by $44.46 \mathrm{~km}^{2}(-13.4 \%)$.

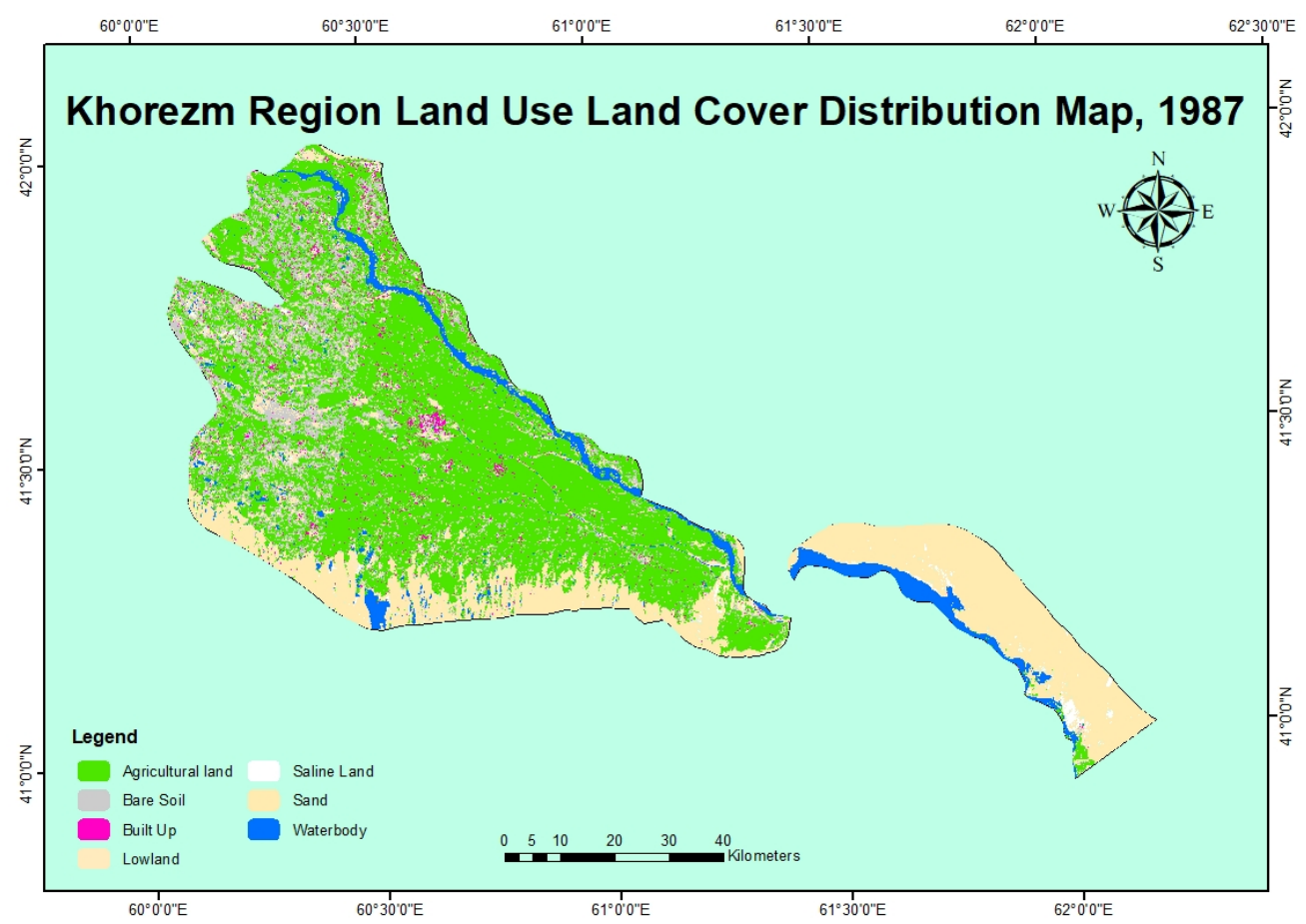

Fig. 2. LULC spatial distribution of Khorezm region, 1987. 


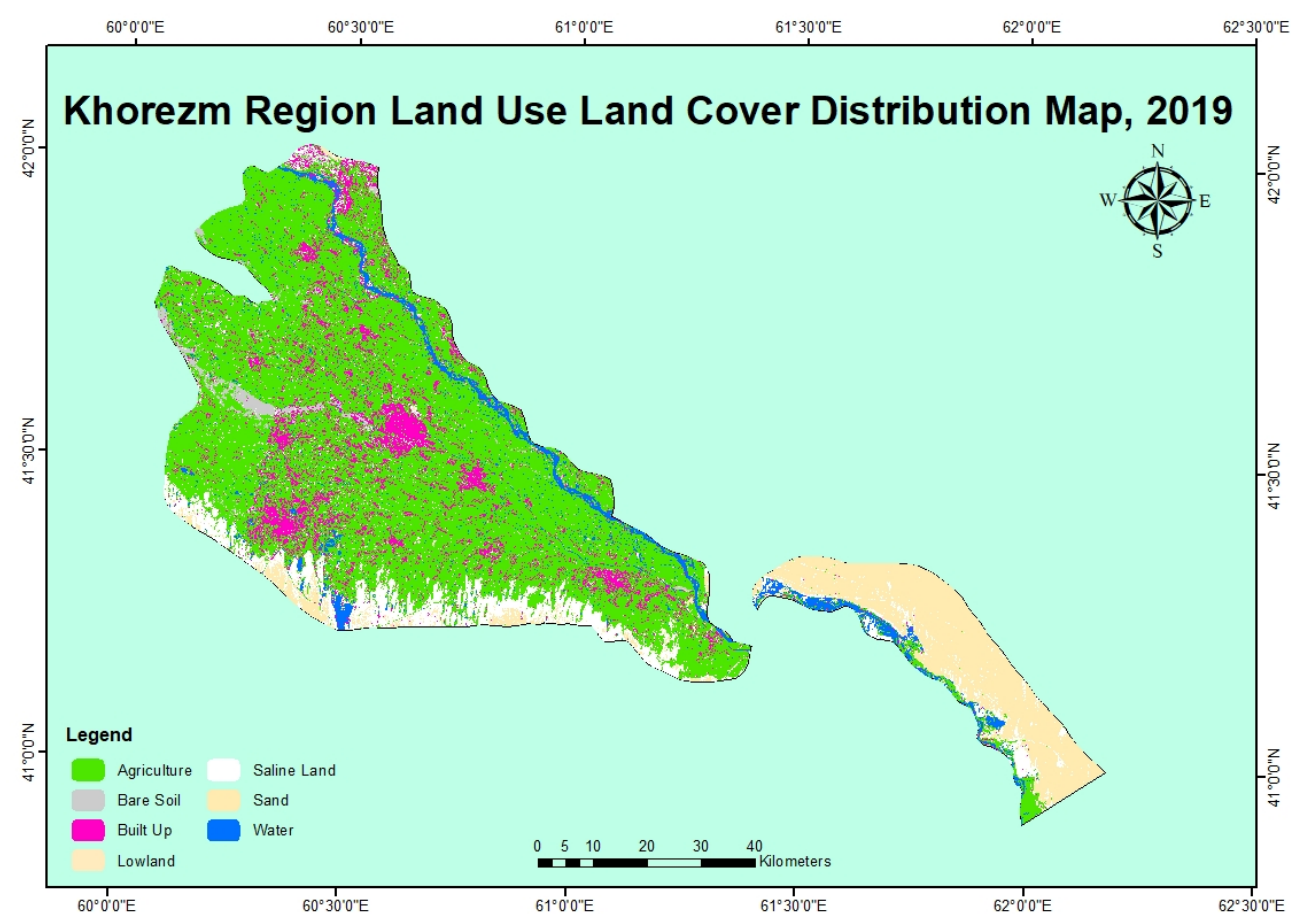

Fig. 3. LULC spatial distribution of Khorezm region, 2019

Above numbers can be discussed as population increased by $60 \%$ (1991-2017) therefore built up area increased accordingly, people gained irrigated land at the expense of hilly areas and bare land to increase agricultural land. Area of agricultural land was increased from $3098,54 \mathrm{~km}^{2}$ to $3661,08 \mathrm{~km}^{2}$, built up area from $123,86 \mathrm{~km}^{2}$ to 610,8 . But Salinized land increased by 11 fold from $50.78 \mathrm{~km}^{2}$ to $599.17 \mathrm{~km}^{2}$. This can be explained as Aral Sea's natural disaster resulted in Khorezm region. Since Uzbekistan, including Khorezm has been facing water scarcity therefore water surface area was decreased by $44.46 \mathrm{~km}^{2}$ ($13.4 \%$ ) in 2019. See table 1.

Table 1. Land use and land cover change (1987-2019).

\begin{tabular}{|c|l|c|c|c|c|}
\hline$\#$ & Land use type & \multicolumn{2}{|c|}{1987} & \multicolumn{2}{c|}{$\mathbf{2 0 1 9}$} \\
\hline 1 & Agricultural Land & 3098,54 & 51,5 & 3661,08 & 60,8 \\
\hline 2 & Built Up & 123,86 & 2,1 & 610,8 & 10,1 \\
\hline 3 & Bare Land & 746,17 & 12,4 & 109,23 & 1,8 \\
\hline 4 & Lowland & 453,79 & 7,5 & 23,47 & 0,4 \\
\hline 5 & Sand & 1216,21 & 20,2 & 730,06 & 12,1 \\
\hline 6 & Water & 332,47 & 5,5 & 288,01 & 4,8 \\
\hline 7 & Saline Land & 50,78 & 0,8 & 599,17 & 9,9 \\
\hline & & $\mathbf{6 0 2 1}, 82$ & $\mathbf{1 0 0 , 0}$ & $\mathbf{6 0 2 1}, 82$ & $\mathbf{1 0 0 , 0}$ \\
\hline
\end{tabular}

We can see on Fig. 3 land in south and southwest of western Khorezm was salinized as well as some areas in east of eastern Khorezm. Agricultural class with increased dynamically. The class rose by $18.2 \%\left(562.54 \mathrm{~km}^{2}\right)$. Increase can discussed as increase in population reflected in the agricultural areas increase, mainly because of subsidence farming: About $75 \%$ of the Khorezm region's population lives in houses with small irrigated land attached to it. People settled within 32 years in place where it was bare land. It is also needed to mention that vast areas of rice plots disappeared in 2019. 
Built-up area was increased in mostly where bare land is. The Built up area, with an increase of $393.1 \%\left(486.94 \mathrm{~km}^{2}\right)$ for the total area of the region. This is obvious since builtup areas expansion is related to the number of population and the population increased from 1066000 to 1776700 in the period between 1991 and 2017. Population density in the Khorezm province is 30.0 per $\mathrm{km}^{2}$, and from 1991 to 2017 the population increased by $66.7 \%$, with an annual average rate of $2.0 \%$. Main income of The Khorezm province's economy is tourism. Because Khiva and Urgench touristic sites are located in Khorezm, and also resorts and children's camps are built in last 30 years within the region, which is another reason for this increase.

The water class on the image mainly represents Amudarya River and lakes, muddy water, suspended water and salty water. In order to get accurate image analysis, we got separate samples for muddy water, suspended water and salty water. Because they scatter differently for each one. Later we united all of them into one as waterbody. By the classified images, a slight change in the waterbody class is detected with a $13.4 \%$ decline $\left(44.46 \mathrm{~km}^{2}\right)$. This result is mainly related with less water coming from Amudary River and water scarcity in general. As we can see that some lakes are disappeared leaving saline land behind.

Bare land area is occurred highest decline, minus $85.4 \%\left(636.94 \mathrm{~km}^{2}\right)$ from the initial area. From Table 2 we can see that the bare soil class has changed to forest and agriculture classes. As the study area befalls the protected zone of Uzbekistan from 1992, the main effort is being paid for the afforestation of the area. Most probably this is the one of the main reasons behind the decline of the bare soil class.

\section{Conclusions}

Remote Sensing tool - ArcMap was used together with Landsat imagery to find out land use and land cover distribution change in Khorezm region. Processed geodata with maximum likelihood classification brought good results for how the land use distribution changed over 32 years. Research find out the significant increase of agricultural land and built up area. Due to rise of population reflected in increasing built up as well as agricultural land. People pushed pressure on natural bare land to gain more space. Also saline land is increased tremendously (11 fold) because of natural disaster (Aral Sea shrink). Strong wind moved salt from former bottom of the Sea to neighboring area, including Khorezm. The most gains at the expense of bare land and lowland areas.

The land use and land cover maps generated from the research will be further used for decision maker from government bodies to think and take action towards softening natural hazards. It might be utilized by local khakimiyat and cadastral bodies to enhance urban and region planning. The LULC distribution maps for 1987 and 2019 alerts ecology specialists that Aral Sea has affecting not only Karakalpakistan but also Khorezm region.

\section{References}

1. E. López, G. Bocco, M. Mendoza, E. Duhau. Predicting land-cover and land-use change in the urban fringe. Landscape and Urban Planning, 55 (4), 271 (2001)

2. P.H. Verburg, K. Neumann, L. Nol. Challenges in using land use and land cover data for global change studies: land use and land cover data for global change studies. Global Change Biology, 17 (2), 974 (2011)

3. Yang, G. Sun. Landsat-Based Land Cover Change in the Beijing-Tianjin-Tangshan Urban Agglomeration in 1990, 2000 and 2010. ISPRS International Journal of GeoInformation, 6 (3), 59 (2017) 
4. P. Gong, J. Wang, L. Yu, Y. Zhao, Y. Zhao, L. Liang, J. Chen. Finer resolution observation and monitoring of global land cover: first mapping results with Landsat TM and ETM+ data. International Journal of Remote Sensing, 34 (7), 2607 (2013)

5. S. Fuchs, V. Röthlisberger, T. Thaler, A. Zischg, M. Keiler. Natural Hazard Management from a Coevolutionary Perspective: Exposure and Policy Response in the European Alps. Annals of the American Association of Geographers, 107 (2), 382 (2017)

6. J.S. Rawat, M. Kumar. Monitoring land use/cover change using remote sensing and GIS techniques: A case study of Hawalbagh block, district Almora, Uttarakhand, India. The Egyptian Journal of Remote Sensing and Space Science, 18 (1), 77 (2015)

7. Ruiz-Luna, C.A. Berlanga-Robles. Land use, land cover changes and coastal lagoon surface reduction associated with urban growth in northwest Mexico. Landscape Ecology, 18 (2), 159 (2003)

8. M.G. Turner, C.L. Ruscher. Changes in landscape patterns in Georgia, USA. Landscape Ecology, 1 (4), 241 (1988)

9. Y. Chen, X. Li, X. Liu, B. Ai. Analyzing land-cover change and corresponding impacts on carbon budget in a fast developing sub-tropical region by integrating MODIS and Landsat TM/ETM+ images. Applied Geography, 45, 10 (2013)

10. F. Yuan, K.E. Sawaya, B.C.Loeffelholz, M.E. Bauer. Land cover classification and change analysis of the Twin Cities (Minnesota) Metropolitan Area by multitemporal Landsat remote sensing. Remote Sensing of Environment, 98 (2-3), 317 (2005)

11. X. Wang, D. Zheng, Y. Shen. Land use change and its driving forces on the Tibetan Plateau during 1990-2000. CATENA, 72 (1), 56 (2008)

12. X. Li, S. Zhao, H. Yang, D. Cong, Z. Zhang. A Bi-Band Binary Mask Based Land-Use Change Detection Using Landsat 8 OLI Imagery. Sustainability, 9 (3), 479 (2017)

13. O.R. Abd El-Kawy, J.K. Rød, H.A. Ismail, A.S. Suliman. Land use and land cover change detection in the western Nile delta of Egypt using remote sensing data. Applied Geography, 31 (2), 483 (2011)

14. H. Yin, A. Khamzina, D. Pflugmacher, C. Martius. Forest cover mapping in postSoviet Central Asia using multi-resolution remote sensing imagery. Scientific Reports, 7 (1) (2017)

15. R. Kraemer, A.V. Prishchepov, D. Müller, T. Kuemmerle, V.C. Radeloff, A. Dara, A. Terekhov, M. Frühauf. Long-term agricultural land-cover change and potential for cropland expansion in the former Virgin Lands area of Kazakhstan. Environmental Research Letters, 10 (5), 054012 (2015)

16. J. Edlinger, C. Conrad, J. Lamers, G. Khasankhanova, T. Koellner. Reconstructing the Spatio-Temporal Development of Irrigation Systems in Uzbekistan Using Landsat Time Series. Remote Sensing, 4 (12), 3972 (2012)

17. D. Jovanovic, M. Govedarica, F. Sabo, Z. Bugarinovic, O. Novovic, T. Beker, M. Lauter. Land cover change detection by using remote sensing: A case study of Zlatibor (Serbia). Geographica Pannonica, 19 (4), 162 (2015)

18. Statistics of Uzbekistan by region. Derived from stat.uz on February 4, 2020.

19. USGS, 2020. Landsat Surface Reflectance. Accessed in April, 2020 (https://www.usgs.gov/core-science-systems/nli/landsat/landsat-collection-1-surfacereflectance) 